\title{
LiDAR Data for Characterizing Linear and Planar Geomorphic Markers in Tectonic Geomorphology
}

Pinliang Dong*

Department of Geography, University of North Texas, Denton, TX 76203, USA

*Corresponding author: Pinliang D, 1155 Union Circle \#305279, Department of Geography, University of North Texas, Denton TX 76203, USA, Tel: 940-565-2377; Email: pdong@unt.edu

Received date: Oct 30, 2014, Accepted date: Nov 24, 2014, Published date: Nov 28, 2014

Copyright: () 2015 Pinliang D. This is an open-access article distributed under the terms of the Creative Commons Attribution License, which permits unrestricted use, distribution, and reproduction in any medium, provided the original author and source are credited.

\begin{abstract}
This paper provides a brief review of airborne light detection and ranging (LiDAR) data for characterizing linear and planar geomorphic markers in tectonic geomorphology, including traces of active faults and surface deformation caused by earthquakes. Challenges and opportunities of LiDAR for the study of tectonic geomorphology and coseismic deformation are also discussed.
\end{abstract}

Keywords: LiDAR; Geomorphic Markers; Geomorphology; Tectonic; Surface deformation

\section{Introduction}

A fundamental theme of tectonic geomorphology is to understand the relation between tectonic processes and surface processes that build and modify topography. Therefore tectonic geomorphology is closely related to geomorphology, tectonics, seismology, geochronology, geodesy, and Quaternary climate change. For over a century, numerous conceptual models of landscape evolution under tectonic and climate regimes have been proposed [1]. To quantify the amount of deformation that has occurred due to tectonic processes, identifiable geomorphic features are needed to provide a reference frame. These geomorphic features are called geomorphic markers [1], including linear geomorphic markers such as streams and glacial moraines, and planar geomorphic markers such as terraces and alluvial fans.

In order to calculate the rates of tectonic movement, there are two important parameters for geomorphic markers: age and geometry. In the past several decades, new geochronologic methods have been developed for determining the age of tectonic and geomorphic markers [1,2]. With increasing accuracy in dating geomorphic features, improvements in quantifying the geometry of geomorphic markers can produce more accurate rates of deformation. Light detection and ranging (LiDAR) is an active remote sensing technology that uses laser pulses to map three-dimensional coordinates of Earth surface features from spaceborne, airborne or ground-based platforms, with sub-meter to centimeter level accuracy, respectively. The last decade has seen wide applications of LiDAR in geomorphic studies. Roering et al. [3] summarized the contribution of airborne LiDAR in geomorphic research in three aspects: (1) providing a detailed base map for field mapping and sample collection, (2) facilitating model testing through increased accuracy and sample sizes, and (3) enabling the identification of unanticipated and sometimes unexplained landforms. Tarolli [4] discussed some opportunities and challenges of LiDAR data for understanding Earth surface processes. This paper provides a brief review of LiDAR data for characterizing linear and planar geomorphic markers in tectonic geomorphology, including traces of active faults and surface deformation caused by earthquakes.

\section{Linear Geomorphic Markers Revealed by LiDAR}

The interactions between tectonic movement, erosion and sedimentation can modify linear geomorphic features. Offset channels associated with strike-slip faults are good examples of linear geomorphic markers that can be used to determine the rate and nature of tectonic movement. While tectonic landforms can be found in many parts of the world, the south-central San Andreas Fault (SAF) in California has arguably some of the world's best-preserved tectonic landforms at $10 \mathrm{~s}$ and $1000 \mathrm{~s}$ of meter scale [5-7]. The most famous offset feature is the offset channel at Wallace Creek across the San Andreas Fault zone in the Carrizo Plain, California [8].

The acquisition of LiDAR data by the B4 project [9] provides new research opportunities for better understanding of the tectonic geomorphology and neotectonic deformation history of the SAF. Arrowsmith and Zielke [10] evaluated the use of LiDAR data for mapping recently active breaks in the Cholame segment of the southcentral SAF, and concluded that a LiDAR-only approach compares well with a combination of aerial photographic and field-based methods. Zielke et al. [11] determined that the average slip along the Carrizo segment of the south-central SAF during the $1857 \mathrm{Mw} 7.9$ earthquake was $5.3 \pm 1.4$ meters. Zielke et al. [12] employed LiDAR data to reevaluate the distribution of surface displacement along the rupture trace of the $1857 \mathrm{Mw} 7.9$ earthquake using 450 offset measurements with displacements below $60 \mathrm{~m}$. Their results show that the 1857 earthquake had an average displacement of less than $3.5 \mathrm{~m}$ with 4-6 m released along the northwestern half of the rupture. To measure lateral displacements of offset linear geomorphic features such as stream channels and alluvial fan edges, Zielke and Arrowsmith [13] developed a Matlab-based tool to visually reconstruct and assess lateral displacements through slicing a digital elevation models (DEM) and back slipping. The LiDAR data for the south-central SAF and relevant case studies have facilitated the application of LiDAR for the quantification of linear geomorphic markers and active faults in general. 
In the Lake Tahoe Basin, California, tectonic offsets of linear glacial moraines have been used to calculate slip rates of active normal faults obscured by dense vegetation. Howle et al. [14] used bare-earth point cloud data to mathematically reconstruct linear lateral moraine crests on both sides of faults. The reconstructed moraine crests produced statistically significant 'piercing lines' that were projected to intersection with modeled fault planes to define 'piercing points' in 3D space. The measured tectonic displacements were coupled with ${ }^{10} \mathrm{Be}$ and ${ }^{26} \mathrm{Al}$ terrestrial cosmogenic nuclide (TCN) surface exposure ages and optically stimulated luminescence (OSL) ages of the displaced moraines to estimate late Pleistocene slip rates. The results of the study yielded a two to three fold increase over previous estimates of tectonic slip rates in the Lake Tahoe region.

LiDAR data have also been used for discovering new active faults and delineating earthquake surface ruptures in vegetated areas. While LiDAR data have been collected over known active fault zones for finescale study of tectonic-geomorphic features (e.g. $[9,15,16])$, new active faults have been discovered using LiDAR data collected from areas that have been overlooked by scientists. For example, Hunter et al. [17] discovered a previously unmapped fault using LiDAR data near the Martis Creek Dam, Truckee, California. Székely et al. [18] used LiDAR data in an extremely flat area, east of Neusiedlersee in Hungary, and discovered linear geomorphic features, which are several hundred meters to several kilometers long. Field investigation and analysis of other geological and geophysical data indicate that the linear features have a neotectonic origin, representing the surface expression of a seismically active fault. In areas with dense vegetation cover in the U.S. Pacific Northwest and Europe, 2-m resolution DEMs derived from LiDAR data have been successfully used for delineating earthquake surface ruptures [19-21]. Using 2-m and 3-m resolution DEMs derived from LiDAR data along portions of the Alpine and Hope faults in New Zealand, Langridge et al. [22] found that the surface strike variations of the Alpine Fault are more variant than previously mapped, and that unprecedented views of the surface geomorphology of these active faults can be revealed by LiDAR data. However, some other LiDAR studies on the northern San Andreas Fault and central Japanese mountains indicated that $2-\mathrm{m}$ resolution DEMs could not identify some small tectonic breaks [23,24]. Using airborne LiDAR data collected from orthogonal flight lines, Lin et al. [25] created $0.5-\mathrm{m}$ resolution DEMs along the Neodani Fault in Japan, and revealed a number of previously unknown fault scarps and active fault traces hidden under dense vegetation. Although the cost of data collection will increase with overlapping flight lines, the greater bare-earth data density, collected from different angles, will likely enhance the imaging of subtle geomorphic markers in densely forested areas.

\section{Planar Geomorphic Markers Revealed by LiDAR}

Planar geomorphic features such as fluvial terraces, alluvial fans, and marine terraces have been widely used as geomorphic markers in tectonic deformation studies [26-33], while erosion surfaces such as pediments $[34,35]$ and glacis [36] have been less used as geomorphic markers due to the difficulty in dating of such surfaces. Several studies have used LiDAR data to analyze tectonic deformation of alluvial fans and marine terraces. Frankel et al. [37] determined new slip rates of the Death Valley-Fish Lake Valley fault system in eastern California and western Nevada by combining alluvial fan offsets measured from 1 -m resolution LiDAR-derived DEM with ${ }^{10} \mathrm{Be}$ TCN and OSL ages from displaced alluvial fans. In a study of deformation variations off the San Andreas Fault, Crosby et al. [38] extracted elevations of the marine terrace inner edges from a LiDAR-derived DEM between Fort Ross and Mendocino, California. Based on the observations, they estimated that the late Pleistocene uplift rate is about $0.75-0.95 \mathrm{~mm} / \mathrm{yr}$ immediately north of the San Andreas Fault, and 0.28-0.38 mm/yr near Mendocino. Bowles and Cowgill [39] presented a semiautomated surface classification method to identify probable marine terraces along a 70-km-long section of the northern California coast using slope and surface roughness properties obtained from LiDARderived DEM. Analysis of 21 observed platform elevations and those predicted from sea-level curves suggests that the surface uplift rate for the northern coast of California has been $0.2 \mathrm{~mm} / \mathrm{yr}$ over the past 2 Ma. In comparison with studies of linear geomorphic markers using LiDAR data, case studies of planar geomorphic markers using LiDAR data are relatively limited.

Planar geomorphic markers can help identify linear geomorphic markers in some cases. For example, if an active fault is hidden beneath an alluvial fan on which a city has been built, it could be very difficult to identify traces of the active fault because of the interference of man-made structures. However, high-resolution topographic profiles of the alluvial fan may reveal traces of the active fault. Kondo et al. [40] provided a good example of identifying a continuous fault scarp using LiDAR data in Matsumoto, a city built on an alluvial fan in central Japan. They created a high-resolution (0.5m) DEM after filtering out laser returns from buildings and vegetation, and identified a fault scarp of up to $2 \mathrm{~m}$ in height using segmented least squares fitting on the topographic profiles derived from the alluvial fan. Borehole data and archaeological studies indicate that the fault scarp is indeed in a pull-apart basin, and were formed during the most recent faulting event associated with historical earthquakes. In the Rangitaiki Plains, the fastest extending section of the onshore Taupo Rift in New Zealand, Begg and Mouslopoulou [41] used fault-parallel and faultnormal profiles created from a LiDAR-derived DEM with $3.5 \mathrm{~m}$ resolution, and identified a vertical displacement of $\sim 3 \mathrm{~m}$ across an active normal fault. Topographic profiles derived from LiDAR data are effective for quantifying vertical displacements caused by active faults.

\section{Surface Deformation Revealed by Differential LiDAR}

Some geological events such as earthquake and volcanic eruption can cause rapid changes in landform. For example, numerous studies have shown that strike-slip earthquakes can cause pressure ridges (mole tracks) and sag basins along active faults $[8,17,42,43]$. In tectonically active areas with multi-temporal LiDAR data coverage, it is possible to use differential LiDAR data for detecting changes in geomorphic markers caused by earthquakes. So far, pre- and postearthquake LiDAR data are available only in deformation zones caused by the following four earthquakes: the $2010 \mathrm{M}_{\mathrm{w}} 7.2 \mathrm{El}$ Mayor-Cucapah earthquake in Mexico [44-47], the $2010 \mathrm{M}_{\mathrm{w}}$ 7.1 Darfield earthquake in New Zealand [48], the $2008 \mathrm{M}_{\mathrm{w}} 6.9$ Iwate-Miyagi earthquake in Japan [49], and the $2011 \mathrm{M}_{\mathrm{w}}$ 7.1 Fukushima-Hamadori earthquake in Japan [49].

Given pre- and post-earthquake LiDAR data, it is relatively straightforward to quantify volumetric changes in topography such as subsidence, uplift, and earthquake-triggered landslides. However, interpreting surface deformation patterns and understanding fault behavior can be more complex because of lateral motions. Leprince et al. [44,50] used image coregistration and sub-pixel correlation methods to calculate horizontal offsets from LiDAR-derived DEMs, which are then back-slipped and differenced to obtain the vertical displacements. Using pre-earthquake LiDAR data collected in 2005 for 
the southern San Andreas, San Jacinto, and Banning faults in California, USA, Borsa and Minster [51] developed a processing algorithm to obtain rapid estimates of near-fault ground deformation using simultaneous cross correlation of both topography and backscatter intensity from pre-earthquake and simulated postearthquake LiDAR datasets. Using differential LiDAR data for the $2010 \mathrm{M}_{\mathrm{w}}$ 7.2 El Mayor-Cucapah earthquake in Mexico, Oskin et al. [45] obtained differential elevation changes that show distributed, kilometer-scale bending strain as large as $\sim 10^{3}$ microstrains along discontinuous faults. As the methods used in Leprince et al. [44,50] and Borsa and Minster [51] involve gridding/smoothing of LiDAR data, biases or artifacts could be introduced in the results. To work with LiDAR point clouds directly, Nissen et al. [46] introduced a new method for calculating 3-D coseismic surface displacements from preand post-earthquake LiDAR data based on the Iterative Closest Point (ICP) algorithm [52,53]. The method was also used to extract threedimensional displacements and rotations from pre- and postearthquake LiDAR data for the 2008 Iwate-Miyagi earthquake and the 2011 Fukushima-Hamadori earthquake in Japan [49]. One limitation of the method by Nissen et al. [46,49] is that it is based on the assumption that all LiDAR points in the compared point clouds have uniform accuracy, whereas the error for each LiDAR point depends on variable factors such as the range from system to target and the incidence angle of laser beam. To take into account the random errors in differential LiDAR point clouds, Zhang et al. [47] developed an error propagation method to generate an estimated random error for each LiDAR point, and obtain 3D displacements between two LiDAR point clouds using an anisotropic weighted ICP algorithm. Surface deformation investigations using pre- and post-earthquake LiDAR data is a relatively new area that will undoubtedly expand with time.

\section{Concluding Remarks}

Many studies have demonstrated the capability of LiDAR for the quantification of linear and planar geomorphic markers in tectonic geomorphology, including active faults and surface deformation caused by earthquakes. In areas with dense vegetation cover, the capability of LiDAR in obtaining bare-earth points allows for delineation of subtle traces of active faults. Coupled with accurate dating techniques and field investigation, LiDAR data can facilitate a better understanding of the patterns and rates of neotectonic deformation. It should be noted that in this review, only airborne LiDAR data are discussed, whereas terrestrial laser scanning (TLS) has been used for characterizing linear geomorphic markers in recent studies [17,54-56].

Major limitations LiDAR include the lack of continuous global data coverage and relatively high cost of data collection. Unlike optical and radar imaging systems that can provide global data coverage through satellite platforms, current LiDAR systems mainly work on airborne and ground-based platforms, and the cost of data collection for large geographic areas can be prohibitive. Moreover, pre- and postearthquake LiDAR are only available for a few earthquake-stricken areas. It is hoped that existing LiDAR datasets will provide an important baseline for surface deformation studies after future earthquakes.

\section{Acknowledgments}

This review is part of the final report for a research project (Project \# 2013LDE008) funded by the Key Laboratory of Digital Earth, Chinese Academy of Sciences. The author would like to thank James
Howle of the U.S. Geological Survey (USGS) and two anonymous reviewers for their helpful comments and suggestions.

\section{References}

1. Burbank DW, Anderson RS (2011) Tectonic Geomorphology. WileyBlackwell.

2. Sloss CR, Westaway KE, Huang Q, Murray-Wallace CV (2013) An Introduction to Dating Techniques: A Guide for Geomorphologists. In Schroder, John (Ed.) Treatise on Geomorphology. Elsevier Inc. 346-369.

3. Roering JJ, Mackey BH, Marshall JA, Sweeney KE, Deligne NI, et al. (2013) 'You are HERE': Connecting the dots with airborne lidar for geomorphic fieldwork. Geomorphology 200: 172-183.

4. Tarolli P (2014) High-resolution topography for understanding Earth surface processes: Opportunities and challenges. Geomorphology 216: 295-312.

5. Wallace RE (1975) The San Andreas fault in the Carrizo Plain-Temblor Range region, California. In: Crowell, J.C. (Ed.), San Andreas Fault in Southern California: A Guide to San Andreas Fault from Mexico to Carrizo Plain. California Division of Mines and Geology Special Report 118: 241-250.

6. Wallace RE, Schulz SS (1983) Aerial views in color of the San Andreas fault, California. U S Geological Survey Open File Report 83-98.

7. Wallace RE (1991) The San Andreas Fault System, California. U.S. Geological Survey, Professional Paper 1515. United States Government Printing Office, Washington D.C.

8. Sieh KE, Jahns RH (1984) Holocene activity of the San Andreas fault at Wallace Creek, California. Geological Society of America Bulletin 95: 883-896.

9. Bevis M, Hudnut K, Sanchez R, Toth C, Grejner-Brzezinska D et al. The B4Project: Scanning the San Andreas and San Jacinto fault zones. Eos Transactions AGU 86 (52) Fall Meet. Suppl. Abstract H34B-01.

10. Arrowsmith JR, Zielke O (2009) Tectonic geomorphology of the San Andreas Fault zone from high resolution topography: An example from the Cholame segment. Geomorphology 113: 70-81.

11. Zielke O, Arrowsmith JR, Ludwig LG, Akciz SO (2010) Slip in the 1857 and Earthquakes Along the Carrizo Plain, San Andreas Fault: Science 327: 1119-1122.

12. Zielke O, Arrowsmith JR, Ludwig LG, Akciz SO (2012) High-Resolution Topography-Derived Offsets along the 1857 Fort Tejon Earthquake Rupture Trace, San Andreas Fault: Bulletin of the Seismological Society of America 102: 1135-1154.

13. Zielke O, Arrowsmith JR (2012) LaDiCaoz and LiDARimagerMATLAB GUIs for LiDAR data handling and lateral displacement measurement: Geosphere 8: 206-221.

14. Howle JF, Bawden GW, Schweickert RA, Finkel RC, Hunter LE, et al. (2012) Airborne LiDAR analysis and geochronology of faulted glacial moraines in the Tahoe-Sierra frontal fault zone reveal substantial seismic hazards in the Lake Tahoe region, Cailfornia-Nevada USA: Geological Society of America Bulletin 124: 5-6.

15. Prentice CS, Crosby CJ, Whitehill CS, Arrowsmith JR, Furlong KP et al. (2009) Illuminating Northern California's active faults. Eos Trans AGU 90: 55 .

16. Liu J, Chen T, Zhang P, Zhang H, Zheng $\mathrm{W}$ et al. (2013) Illuminating the Active Haiyuan Fault, China by Airborne Light Detection and Ranging. Chinese Science Bulletin 58: 41-45.

17. Hunter LE, Howle JF, Rose RS, Bawden GW (2009) The "Polaris Fault": A previously unmapped fault discovered using LiDAR near Martis Creek Dam, Truckee, CA. Seismological Research Letters 80: 305.

18. Szekely A, Zamolyi A, Draganits E, Briese C (2009) Geomorphic expression of neotectonic activity in a low relief area in an Airborne Laser Scanning DTM: A case study of the Little Hungarian Plain (Pannonian Basin). Tectonophysics 474: 353-366. 
19. Haugerud RA, Harding DJ, Johnson SY, Harless JL, Weaver CS et al (2003) High-resolution topography of the Puget Lowland, Washington - a bonanza for earth science. GSA Today 13: 4-10.

20. Sherrod BL, Brocher TM, Weaver CS, Bucknam RC, Blakely RJ et al. (2004) Holocene fault scarps near Tacoma,Washington, USA. Geology 32: 9-12.

21. Cunningham D, Grebby S, Tansey K, Gosar A, Kastelic V (2006) Application of airborne LiDAR to mapping seismogenic faults in forested mountainous terrain, southeastern Alps, Slovenia. Geophysical Research Letter 33: L20308.

22. Langridge RM, Ries WF, Farrier T, Barth NC, Khajavi N, et al. (2014) Developing sub 5-m LiDAR DEMs for forested sections of the Alpine and Hope faults, South Island, New Zealand: Implications for structural interpretations. Journal of Structural Geology 64: $53-66$.

23. Zachariasen J (2008) Detail mapping of the northern San Andreas Fault using LiDAR imagery. Final Technical Report of National Earthquake Hazards Reduction Program. 1-47.

24. Lin Z, Kaneda H, Mukoyama S, Asada N, Chiba T (2009) Detection of small tectonic-geomorphic features beneath dense vegetation covers in Japanese mountains from high-resolution LiDAR DEM. Seismological Research Letters 80: 311-312.

25. Lin Z, Kaneda H, Mukoyama S, Asada N, Chiba T (2013) Detection of subtle tectonic-geomorphic features in densely forested mountains by very high-resolution airborne LiDAR survey. Geomorphology 182: 104115.

26. Goy JL, Zazo C (1986) Synthesis of the Quaternary in the Almería littoral neotectonic activity and its morphologic features, Western Betics, Spain. Tectonophysics 130: 259-270

27. Hetzel R, Niedermann S, Tao M, Kubik PW, Ivy-Ochs S, et al. (2002) Low slip rates and long-term preservation of geomorphic features in Central Asia. Nature 417: 428-432.

28. Silva P, Goy J, Zazo C, Bardaji T (2003) Fault-generated mountain fronts in southeast Spain: geomorphologic assessment of tectonic and seismic activity. Geomorphology 50: 203-225.

29. Hetzel R, Niedermann S, Tao M, Kubik PW, Ivy-Ochs S, et al. (2002) Low slip rates and long-term preservation of geomorphic features in Central Asia. Nature 417: 428-432.

30. Kubik PW (2004) Late Pleistocene//Holocene slip rate of the Zhangye thrust (Qilianshan, China) and implications for the active growth of the northeastern Tibetan Plateau. Tectonics 23.

31. Filocamo F, Romano P, Di Donato V, Esposito P, Mattei M et al. (2009) Geomorphology and tectonics of uplifted coasts: new chronostratigraphical constraints for the Quaternary evolution of Tyrrhenian North Calabria (southern Italy). Geomorphology 105: 334354.

32. Ramos NT, Tsutsumi H, Perez JS, Bermas PP (2012) Uplifted marine terraces in Davao Oriental Province, Mindanao Island, Philippines and their implications for large prehistoric offshore earthquakes along the Philippine trench. Journal of Asian Earth Sciences 45: 114-125.

33. Gurrola LD, Keller EA, Chen JH, Owen LA, Spencer JQ (2013).Tectonic geomorphology of marine terraces: Santa Barbara fold belt, California. Geological Society of America Bulletin 126: 219-233.

34. Matsu'ura T, Kimura H, Komatsubara J, Goto N, Yanagida M, Ichikawa $\mathrm{K}$ et al. (2014) Late Quaternary uplift rate inferred from marine terraces, Shimokita Peninsula, northeastern Japan: A preliminary investigation of the buried shoreline angle. Geomorphology 209: 1-17.

35. Hetzel R, Tao MX, Stokes S, Niedermann S, Ivy-Ochs S et al. (2004) Implications of the fault scaling law for the growth of topography: mountain ranges in the broken foreland of NE Tibet. Terra Nova 16: 157-162.

36. Hall SR, Farber DL, Audin L, Finkel RC, Mériaux S (2008) Geochronology of pediment surfaces in southern Peru: implications for Quaternary deformation of the Andean forearc. Tectonophysics 459: 186-205.
37. García-Tortosa FJ, Alfaro P, Sanz de Galdeano C, Galindo-Zaldívar J (2011) Glacis geometry as a geomorphic marker of recent tectonics: The Guadix-Baza basin (South Spain). Geomorphology 125: 517-529.

38. Frankel KL, Dolan JF, Owen LA, Ganev P, Finkel RC (2011) Spatial and temporal constancy of seismic strain release along an evolving segment of the Pacific-North America plate boundary. Earth and Planetary Science Letters 304: 565-576.

39. Crosby CJ, Arrowsmith JR, Prentice CS (2006) Application of LiDAR data to constraining a late Pleistocene slip rate and vertical deformation of the Northern San Andreas Fault, Fort Ross to Mendocino, California: Collaborative research between Arizona State University and the U.S. Geological Survey, in 3rd Annual Northern California. Earthquake Hazards Workshop abstract volume, Menlo Park, CA.

40. Bowles CJ, Cowgill E (2012) Discovering marine terraces using airborne LiDAR along the Mendocino-Sonoma coast, northern California. Geosphere 8: 386-402.

41. Kondo H, Toda S, Okumura K, Takada K, Chiba T (2008) A fault scarp in an urban area identified by LiDAR survey: A Case study on the Itoigawa-Shizuoka Tectonic Line, central Japan. Geomorphology 101: 731-739.

42. Begg JG, Mouslopoulou V (2010) Analysis of late Holocene faulting within an active rift using lidar, Taupo Rift, New Zealand. Journal of Volcanology and Geothermal Research 190: 152-167.

43. Ren Z, Lin A (2010) Deformation characteristics of co-seismic surface ruptures produced by the 1850 M7.5 Xichang earthquake on the eastern margin of the Tibetan Plateau. Journal of Asian Earth Sciences 38: 1-13.

44. Li C, Pang J, Zhang Z (2012) Characteristics, Geometry, and Segmentation of the Surface Rupture Associated with the 14 April 2010 Yushu Earthquake, Eastern Tibet, China. Bulletin of the Seismological Society of America, 102: 1618-1638.

45. Leprince S, Hudnut KW, Akciz SO, Hinojosa-Corona A, Fletcher JM (2011) Surface rupture and slip variation induced by the 2010 El MayorCucapah earthquake, Baja California, quantified using COSICorr analysis on pre- and post-earthquake LiDAR acquisitions. AGU San Francisco, Calif. 5-9 Dec.

46. Oskin ME, Arrowsmith JR, Hinojosa Corona A, Elliott AJ, Fletcher JM, et al. (2012) Near-field deformation from the El Mayor-Cucapah earthquake revealed by differential LIDAR. Science 335: 702-705.

47. Nissen E, Krishnan AK, Arrowsmith JR, Saripalli S (2012) Threedimensional surface displacements and rotations from differencing preand post-earthquake LiDAR point clouds. Geophysical Research Letters 39: L16301.

48. Zhang X, Kusari A, Glennie CL, Oskin ME, Hinojosa-Corona A et al. (2013) Change Detection from differential airborne LiDAR using a weighted Anisotropic Iterative Closest Point Algorithm. American Geophysical Union, Fall Meeting 2013.

49. Duffy B, Quigley M, Barrell DJA, Van Dissen R, Stahl T et al. (2013) Fault kinematics and surface deformation across a releasing bend during the 2010 Mw 7.1 Darfield, New Zealand, earthquake revealed by differential LiDAR and cadastral surveying. GSA Bulletin: 125: 420-431.

50. Nissen E, Maruyama T, Arrowsmith JR, Elliott JR, Krishnan AK (2014) Coseismic fault zone deformation revealed with differential lidar: Examples from Japanese $\mathrm{Mw} \sim 7$ intraplate earthquakes. Earth and Planetary Science Letters 405: 244-256.

51. Leprince S, Berthier E, Ayoub F, Delacourt C, Avouac JP (2008) Monitoring Earth surface dynamics with optical imagery, Eos Trans. AGU, 89: 1 .

52. Borsa A, Minster JB (2012) Rapid Determination of Near-Fault Earthquake Deformation Using Differential LiDAR. Bulletin of the Seismological Society of America. 102:1335-1347.

53. McCane B, King TI, Abbott JH (2006) Calculating the 2D motion of lumbar vertebrae using splines. J Biomech 39: 2703-2708.

54. Chen Y, Medioni G (1992) Object modelling by registration of multiple range images. Image and Vision Computing 10: 145-155. 
Citation: Dong P (2015) LiDAR Data for Characterizing Linear and Planar Geomorphic Markers in Tectonic Geomorphology. J Geophys Remote Sensing 4: 136. doi:10.4172/2169-0049.1000136

Page 5 of 5

55. Wiatr T, Reicherter K, Papanikolaou I, Fernández-Steeger T, Mason J (2013) Slip vector analysis with high resolution t-LiDAR scanning. Tectonophysics 608: 947-957.

56. Wilkinson M, Roberts GP, McCaffrey K, Cowie PA, FaureWalker JP et al. (2014) Slip distributions on active normal faults measured from LiDAR and field mapping of geomorphic offsets: an example from L'Aquila, Italy, and implications for modelling seismic moment release. Geomorphology. 